\title{
Whole Ecosystem Evidence of Eutrophication Enhancement by Wetland Dredging in a Shallow Tropical Lake
}

\author{
Humberto Marotta • Luiz Bento • \\ Francisco de A. Esteves • Alex Enrich-Prast
}

Received: 12 November 2007 /Revised: 22 January 2009/Accepted: 4 March 2009/Published online: 3 April 2009

(C) Coastal and Estuarine Research Federation 2009

\begin{abstract}
The purpose of this research was to assess the effects of dredging performed in a marginal wetland colonized by aquatic macrophytes on eutrophication of the adjacent shallow tropical lake (Imboassica Lake, Brazil). The river mouth of the Imboassica River that drains into Imboassica Lake had been densely colonized by aquatic vegetation dominated by Typha domingensis (Pers.) when it was dredged. Total and dissolved nitrogen and phosphorus concentrations were measured monthly over 13 years at four stations in the Imboassica river-lake system. Dredging activities reduced phosphorus and nitrogen retention at the river mouth and subsequently increased these nutrient stocks in the lake waters. Nutrient retention by non-dredged wetland was estimated to be ca. $1,200 \mathrm{~kg} \mathrm{year}^{-1}\left(87.3 \mathrm{~g} \mathrm{~m}^{-2}\right.$ year $\left.^{-1}\right)$ for nitrogen and $60 \mathrm{~kg}$ year $^{-1}\left(4.5 \mathrm{~g} \mathrm{~m}^{-2}\right.$ year $\left.^{-1}\right)$ for phosphorus. Our whole-lake approach suggested that dredging might intensify rather than mitigate eutrophication in shallow tropical lakes when the removal of aquatic macrophytes is coupled to the persistence of anthropogenic nutrient inputs from the watershed.
\end{abstract}

\footnotetext{
H. Marotta $\cdot$ L. Bento $\cdot$ A. Enrich-Prast $(\square)$

Laboratório de Biogeoquímica, Inst. de Biologia,

Depto. de Ecologia,

Universidade Federal do Rio de Janeiro (UFRJ),

PO Box 68020, Prédio CCS, Av. Carlos Chagas Filho 373,

Ilha do Fundão,

Rio de Janeiro 21941-902, Brazil

e-mail: aeprast@biologia.ufrj.br

H. Marotta $\cdot$ L. Bento

Programa de Pós-Graduação em Ecologia (PPGE) Prédio CCS, Universidade Federal do Rio de Janeiro (UFRJ),

Av. Carlos Chagas Filho 373, Ilha do Fundão,

Rio de Janeiro 21941-902, Brazil

\section{F. A. Esteves}

Laboratório de Limnologia, Inst. de Biologia, Depto. de Ecologia,

Universidade Federal do Rio de Janeiro (UFRJ),

PO Box 68020, Prédio CCS, Av. Carlos Chagas Filho 373,

Ilha do Fundão,

Rio de Janeiro 21941-902, Brazil
}

Keywords Dredging · Nutrient retention · Eutrophication · Shallow tropical lakes · Typha domingensis (Pers.) · Wetlands

\section{Introduction}

Lakes are aquatic ecosystems distributed broadly in the terrestrial surface (Downing et al. 2006), constituting an important destination for allochthonous (Lennon 2004; Sobek et al. 2005) and autochthonous (Brevik and Homburg 2004) matter in the watershed. Organic and inorganic inputs into lakes may originate from anthropogenic point and non-point sources (Arbuckle and Downing 2001). One recognizable consequence of pollution by nutrient-enriched effluents is the growth of submerged (Rooney et al. 2003), floating (Kadlec and Knight 1996) and emergent (Gophen 2000) aquatic macrophytes.

Emergent aquatic macrophytes are often abundant in wetlands - transitional habitats between aquatic and terrestrial ecosystems that are inundated or saturated by water during part or all of the year (Neue et al. 1997). Wetlands may mitigate eutrophication at low cost (Verhoeven and Meuleman 1999), showing great potential as complementary sewage treatment systems, even for big cities (CostaPierce 1998). Aquatic macrophytes reduce organic matter inputs (Wentz 1987) and contribute to retention of nutrients, mainly nitrogen (Fleischer et al. 1991) and phosphorus (Kadlec 1997), in aquatic ecosystems. This nutrient retention, or the difference between nutrient inputs and outputs, is caused by biological activity, sedimentation and chemical reduction to gases (Saunders and Kalff 2001). The role of emergent aquatic macrophytes in nutrient retention might be especially important in shallow lakes at low latitudes, where tropical conditions favor the colonization of these plants in marginal wetlands (Wetzel 1990).

Eutrophication contributes to silting in lakes because it increases autochthonous primary production and organic 
matter sedimentation (Brevik and Homburg 2004). The removal of peat sediments through dredging is considered an important intervention to restore the nutrient assimilative capacity of enriched lakes by reducing the internal loading from the sediment to the water column (Ruley and Rusch 2002). Hence, dredging may restore eutrophic aquatic ecosystems, increasing depth and reducing nutrient stocks (Sagehashi et al. 2001). However, this intervention may also remove the aquatic macrophytes that play an important role in nutrient retention in lakes (Rooney et al. 2003).

Here, we assessed the effects of dredging in a marginal wetland densely colonized by aquatic macrophytes on the eutrophication of the adjacent shallow tropical lake. This wetland is situated in a small river mouth that drains into the lake. Dredging restored fluvial depth and water flow into the lake by removing a large amount of sediment and aquatic vegetation, growth of which had been encouraged by the shallow depth and input of anthropogenic-generated nutrients. However, nutrient input from sewage into the river remained unchanged, allowing us to assess the role of dredging and removal of aquatic macrophytes on lake eutrophication at an ecosystem scale. We compared nitrogen $(\mathrm{N})$ and phosphorus $(\mathrm{P})$ concentrations in the water column of both river and lake for three periods over 13 years: two before and one after the dredging. Our hypothesis was that dredging with removal of aquatic macrophytes that was not coupled with a reduction in nutrient input would increase eutrophication in a shallow tropical lake.

\section{Materials and Methods}

\section{Study Area}

The tropical catchment studied here is located in the North region of Rio de Janeiro State, Brazil (Fig. 1). Imboassica River, a fourth order stream of about $14 \mathrm{~km}$ in length, is the main tributary of the Imboassica Lake watershed (area= $55 \mathrm{~km}^{2}$; and maximum altitude $120 \mathrm{~m}$ ). The predominant land use in this watershed is abandoned pasture fields with residual native vegetation. However, the lowlands next to Imboassica Lake are dominated by urban use resulting in domestic sewage discharges directly into this aquatic ecosystem from its margins or from its tributary (Imboassica River), representing two different nutrient sources into the lake. Imboassica Lake $\left(3.26 \mathrm{~km}^{2}\right)$ is a coastal, shallow (mean depth=1.4 m), and brackish-water (mean salinity=5 US) ecosystem. Sewage inputs and siltation have increased, mainly since 1995. The marginal area of Imboassica Lake is densely colonized by emergent aquatic macrophytes (especially Southern cattail, Typha domingensis Pers.) at ca. $2,000 \mathrm{~g} \mathrm{DW} \mathrm{m}^{-2}$ in an area of $0.5 \mathrm{~km}^{2}$ or about $15 \%$ of the total area of this lake (estimated by Palma-Silva 1998).

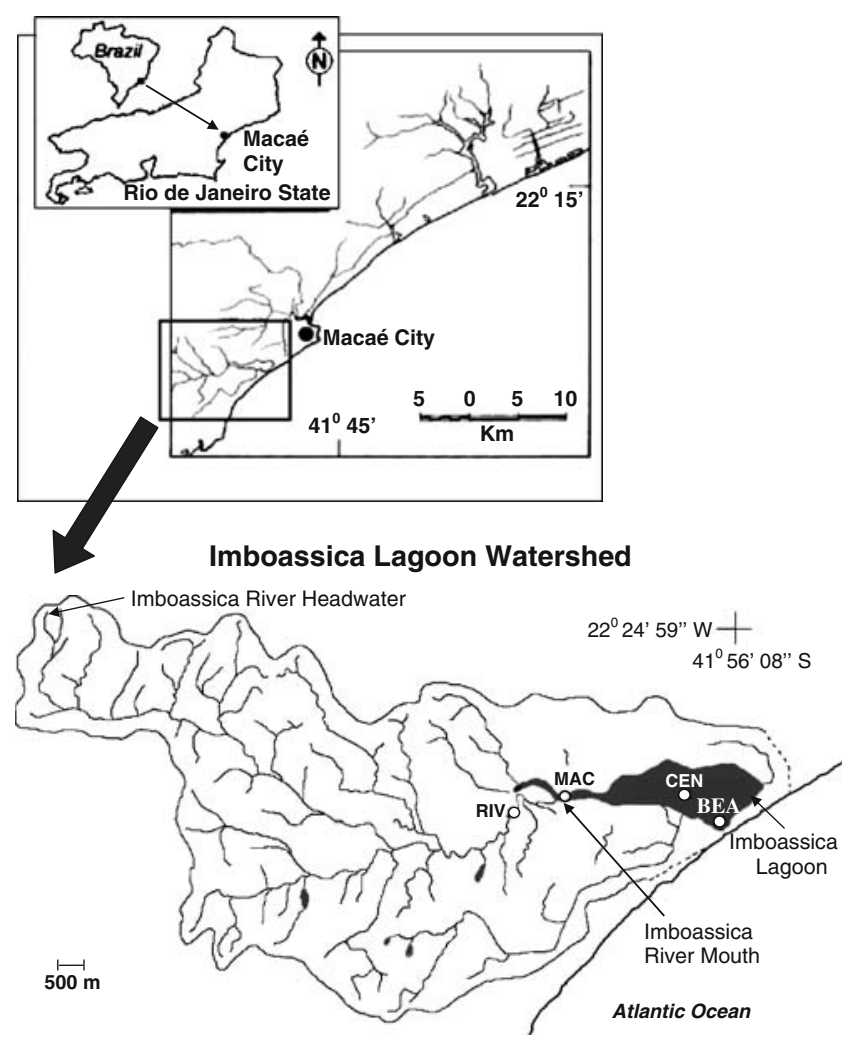

Fig. 1 Geographic localization of the Imboassica Lake watershed in Brazil. White circles Sampling stations: RIV, MAC, CEN and BEA (see Materials and Methods for details)

Wetland covering an area of $14,000 \mathrm{~m}^{2}$ (extending for $2 \mathrm{~km}$ and with a width of $7 \mathrm{~m}$ ) in the Imboassica River and its mouth into Imboassica Lake was dredged. This dredging removed aquatic macrophytes and peat sediments during the period from July to September 2002.

Sampling Stations and Periods

Water samples for $\mathrm{N}$ and $\mathrm{P}$ measurements were collected monthly from four stations (Fig. 1): RIV-at the Imboassica River, $2 \mathrm{~km}$ upstream from the river mouth that drains into Imboassica Lake; MAC - at the Imboassica Lake, in an area close to the Imboassica River mouth; $\mathrm{CEN}$ - at the central area of Imboassica Lake; and BEA-located close to the large sandbar that separates the lake from the sea, constituting the station farthest from the river mouth. Water sampling at each station was performed during three periods:

1 More Pristine (PRIST) - from May 1992 to December 1994 (32 months): Imboassica Lake and Imboassica River showed more oligotrophic characteristics. The river mouth of the Imboassica river-lake system had a permanent water flow (ca. $5 \mathrm{~m}^{3} \mathrm{~s}^{-1}$ ) and aquatic macrophytes were absent along the river shore. 
2 Before Dredging (BD) - from January 2000 to June 2002 (30 months): the mouth of Imboassica River became densely colonized by $T$. domingensis due to eutrophication. In this area, a permanent superficial water column persisted only at the RIV station, as the river section from this point to Imboassica Lake no longer flowed superficially because of silting, showing only a groundwater flow. This lake had also been eutrophicated by sewage inputs directly from the margins; the average flow in the main discharge channel was estimated at $82.5 \mathrm{~L} \mathrm{~s}^{-1}$ (Lopes-Ferreira 1998).

3 After Dredging (AD) - from May 2003 to October 2005 (28 months): dredging of the river channel restored the water flow between Imboassica River and Imboassica Lake to values similar to those of the PRIST period (ca. $4 \mathrm{~m}^{3}$ $\mathrm{s}^{-1}$ ). However, comparing the periods before and after dredging, nutrient discharges in the Imboassica River were not enhanced. A marked reduction in the sewage inflow directly from the margins of Imboassica Lake with respect to the $\mathrm{BD}$ period was measured, showing mean values of $16 \mathrm{~L} \mathrm{~s}^{-1}$ in the main discharge channel (Silva 2006).

Assessment of Dredging Effects on Eutrophication in the Water Column of Imboassica Lake

Dredging effects on eutrophication in the lake were assessed using two approaches: (1) analyzing changes in
$\mathrm{N}$ and $\mathrm{P}$ concentrations (total and dissolved forms) among sampling stations and periods, and (2) comparing $\mathrm{N}$ and $\mathrm{P}$ standing stocks (mass of total and dissolved forms) in lake water among sampling periods. We assumed that the increase in a given nutrient $(\mathrm{N}$ or $\mathrm{P})$ in lake water between PRIST and BD periods was influenced mainly by non-fluvial sources (sewage discharges directly from lake margins). We considered that fluvial nutrient inputs into the lake during this time interval were lower by the initial level of eutrophication in PRIST and due to the strong river mouth silting in $\mathrm{BD}$. The increase in a given nutrient during the time interval just before and after dredging was considered to be due to both non-fluvial and post-dredging fluvial sources. Further, dredging effects on total nutrient standing stock in lake water was assessed by the difference in the increased rate per year of total $\mathrm{N}$ and $P$ mass between two time intervals: 5 years from PRIST to $\mathrm{BD}$ and 1 year from $\mathrm{BD}$ to $\mathrm{AD}$. In this estimate, we estimated conservatively that nutrient inputs directly from the margins into Imboassica Lake by non-fluvial sources between both time intervals were similar, despite an important flow reduction observed in the main sewage discharge channel (see preceding section). Calculations to estimate the effects of dredging on total $\mathrm{N}$ or $\mathrm{P}$ standing stocks in the lake are described below:

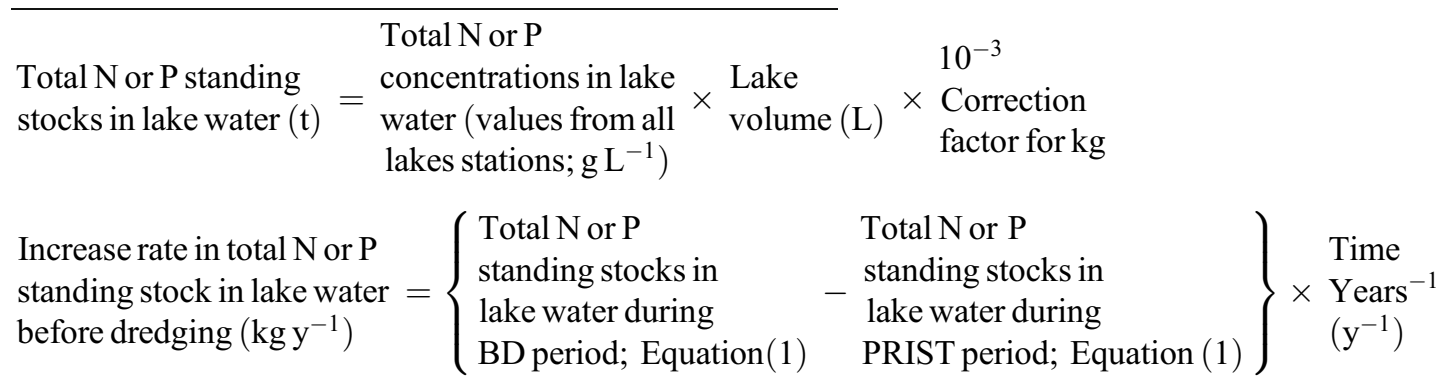

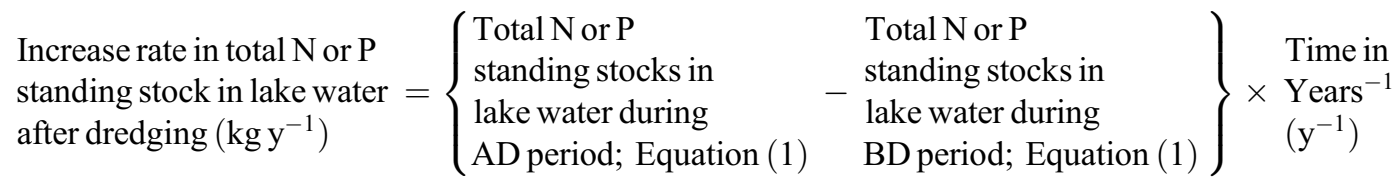
Dredging effects on
Increase rate in total $\mathrm{N}$
total $\mathrm{N}$ or P standing $=$ or P standing stocks in
stocks in the lake water $=$ lake water after
Increase rate in total $\mathrm{N}$
or P standing stocks in
lake water before
$\left(\mathrm{kg} \mathrm{y}^{-1}\right)$
dredging $\left(\mathrm{kg} \mathrm{y}^{-1}\right)$; Equation (3)
dredging $\left(\mathrm{kg} \mathrm{y}^{-1}\right)$; Equation(2)

\section{Analytical Methods}

Water samples were collected with a Van Dorn bottle, transported to a field laboratory, filtered through $1.2 \mu \mathrm{m}$ glass fiber filters (GF/C Whatman) for dissolved forms analyses and frozen. Total and dissolved $\mathrm{N}$ concentrations were obtained by the sum of Kjeldahl nitrogen (Mackereth et al. 1978) and nitrate (Golterman et al. 1978) concentrations. Total and dissolved $\mathrm{P}$ concentrations were determined by the blue molybdenum method (Golterman et al. 1978). 


\section{Statistical Analysis}

Transformed data did not meet the assumptions of parametric tests (Zar 1996); the data were not normally distributed (Kolmogorov-Smirnov, $P<0.05$ ) and variances were heterogeneous (Bartlett, $P<0.05$ ). Medians and a nonparametric test were used to compare sampling groups (Kruskal-Wallis, $P<0.05$; Zar, 1996). Statistical tests were carried out using GraphPad Prism 4.0. After this step, pairto-pair differences were assessed with False Discovery Rate (FDR; $P<0.05$ ), considering $P$-values from Mann-Whitney tests and a specific lambda equal to zero (Benjamini and Hochberg 1995). FDR was calculated using the software Q-VALUE, as this approach may be more powerful than traditional Bonferroni corrections and deserves more frequent use in ecological field studies, especially in those involving a relatively large number of multiple comparisons (Garcia 2004).

\section{Results}

$\mathrm{N}$ and $\mathrm{P}$ concentrations in all sampling stations were significantly lower in the PRIST period with respect to after dredging (FDR; $P<0.05$; Figs. 2, 3, 4, 5). Nutrient concentrations at the river station increased strongly between the periods PRIST and BD (FDR; $P<0.05$ ), but no significant differences were observed comparing these periods at the lake station next to the river (MAC) and for dissolved forms at other lake stations (CEN and BEA;

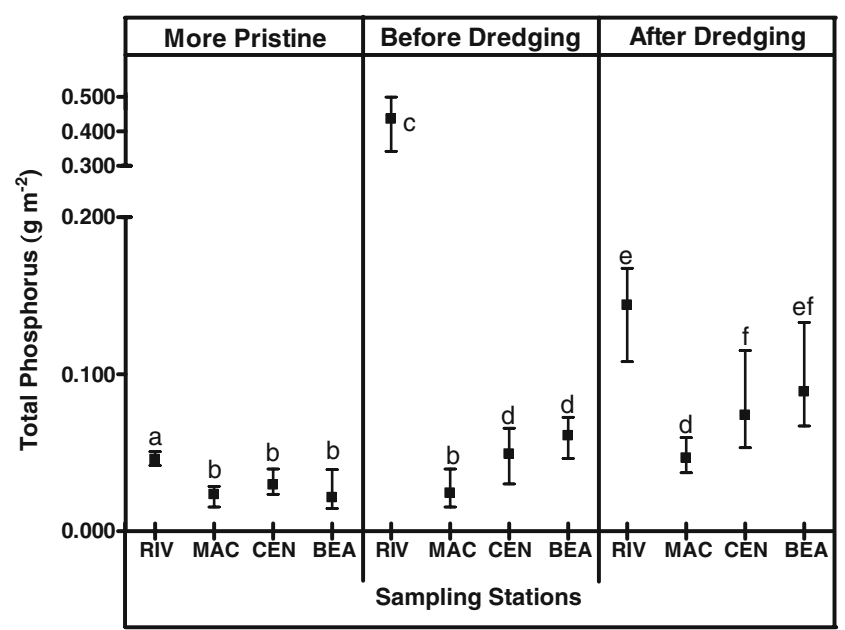

Fig. 2 Dissolved phosphorus $(\mathrm{P})$ concentrations in the three study periods: more pristine (PRIST; $n=32$ months from 1992 to 1994), before dredging (BD; $n=30$ months from 2000 to 2002), and after dredging ( $n=28$ months from 2003 to 2005). Black squares and error bars represent the median and 25-75\% interquartile interval, respectively. The same lower case letters represent no significant difference among sampling stations and periods $[P>0.05$; false discovery rate (FDR)]. Note break in scale on the $y$-axis

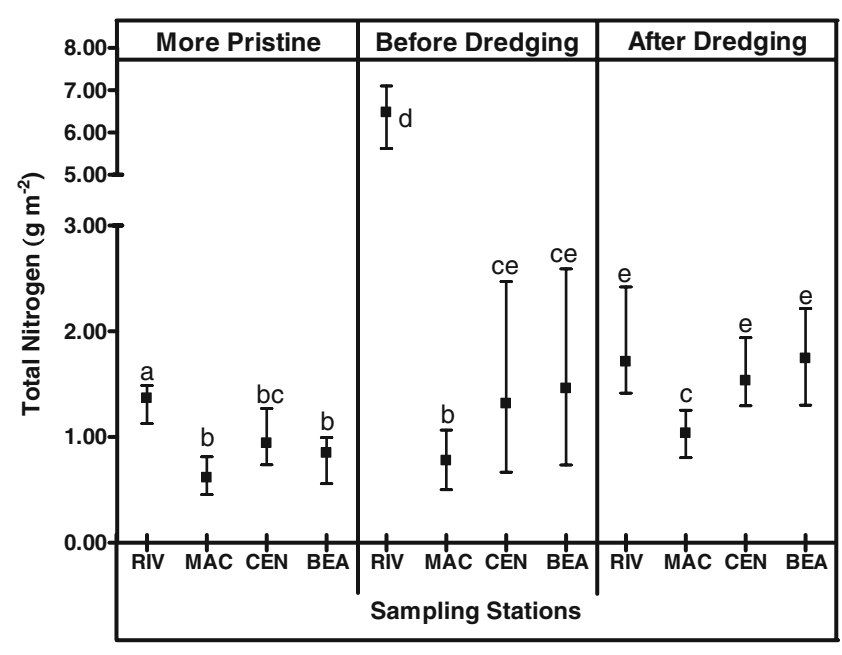

Fig. 3 Dissolved nitrogen $(N)$ concentrations in the three study periods. Descriptions of sampling stations and statistics as in Fig. 2

FDR; $P>0.05$; Figs. 2, 3, 4, 5). Before dredging, the river station showed the maximum difference of $\mathrm{N}$ and $\mathrm{P}$ concentrations in relation to lake stations, with median values between 6 and 10 times higher. Comparing the periods before and after dredging, nutrient concentrations decreased significantly at the river station and increased in all lake stations (FDR; $P<0.05$, Figs. 2, 4, 5), except total N in CEN and BEA (FDR; $P>0.05$, Fig. 3).

Standing stocks of dissolved and total $\mathrm{N}$ and dissolved $\mathrm{P}$ in the water column of Imboassica Lake showed no significant changes between the two first periods, PRIST and BD (FDR; $P>0.05$, Fig. 6), and a significant increase (ca. 108, 37 and $165 \%$, respectively) comparing the periods $\mathrm{BD}$ and $\mathrm{AD}$ (FDR; $P<0.05$, Fig. 6). The standing stock of total $\mathrm{P}$ was characterized by a significant increase in both time intervals between study periods

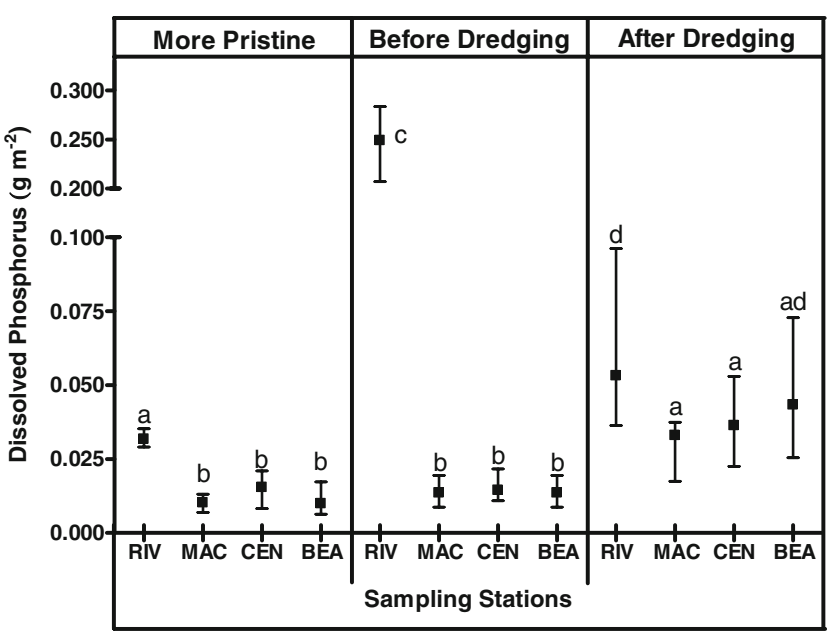

Fig. 4 Total $\mathrm{P}$ concentrations in the three study periods. Descriptions of sampling stations and statistics as in Fig. 2 


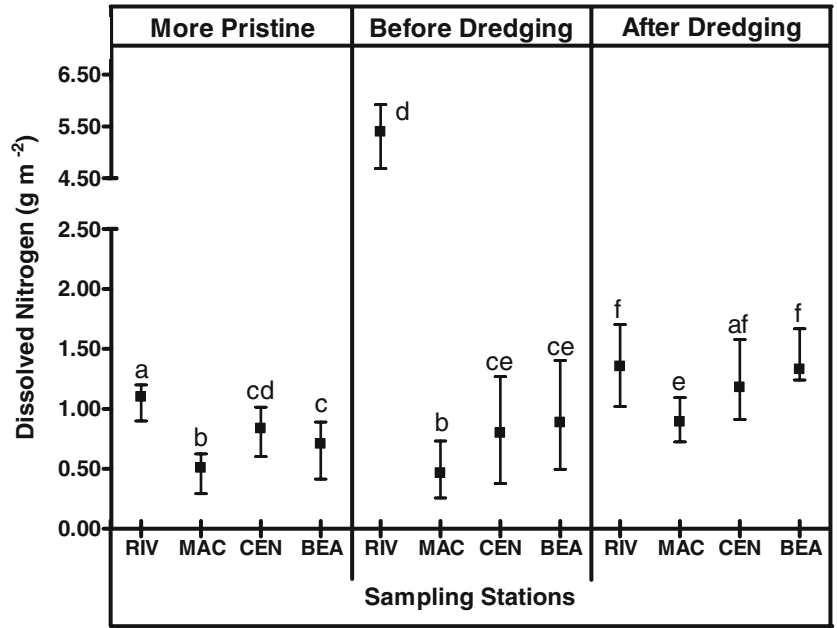

Fig. 5 Total $\mathrm{N}$ concentrations in the three study periods. Descriptions of sampling stations and statistics as in Fig. 2

(FDR; $P<0.05$ ), about $80 \%$ in the 5 years from PRIST to $\mathrm{BD}$, and about $50 \%$ in only 1 year from $\mathrm{BD}$ to $\mathrm{AD}$ (Fig. 6). The increased rate due to dredging activities in the studied wetland was estimated as $1,222 \mathrm{~kg} \mathrm{year}^{-1}$ for total $\mathrm{N}$ and $63 \mathrm{~kg}_{\text {year }}{ }^{-1}$ for total $\mathrm{P}$ (Table 1). Considering the area of $14,000 \mathrm{~m}^{2}$ of dredged wetland, the nutrient retention per area was estimated as $87.3 \mathrm{~g} \mathrm{~N} \mathrm{~m}^{-2}$ year $^{-1}$ and $4.5 \mathrm{~g} \mathrm{P} \mathrm{m}^{-2}$ year $^{-1}$.

\section{Discussion}

Nutrient inputs from the watershed over 13 years resulted in a general enrichment of $\mathrm{N}$ and $\mathrm{P}$ at all sampling stations. The highest $\mathrm{N}$ and $\mathrm{P}$ concentrations observed at the river station when the river mouth was silted up (before dredging) might be attributed to factors other than just increases in sewage discharges. The very low water flow also influenced this result, as this would reduce nutrient dilution and contribute to eutrophication in natural waters (Schindler 2006).

Despite the strong eutrophication in Imboassica River, the lake station closest to this river (MAC) did not show a significant nutrient enrichment before dredging, probably due to dense colonization by aquatic macrophytes in the Imboassica river-lake system during this sampling period. Wetlands colonized by aquatic macrophytes can remove significant amounts of P (Kadlec 1997) and N (Saunders
Fig. 6 Standing stocks of $\mathrm{P}$ (white bars) and $\mathrm{N}$ (grey bars) in the water column of Imboassica Lake. a Dissolved, b total. Sampling periods as in Fig. 2. The same lower case letters for each variable represents no significant difference among periods $(P>0.05$; FDR $)$ (a)

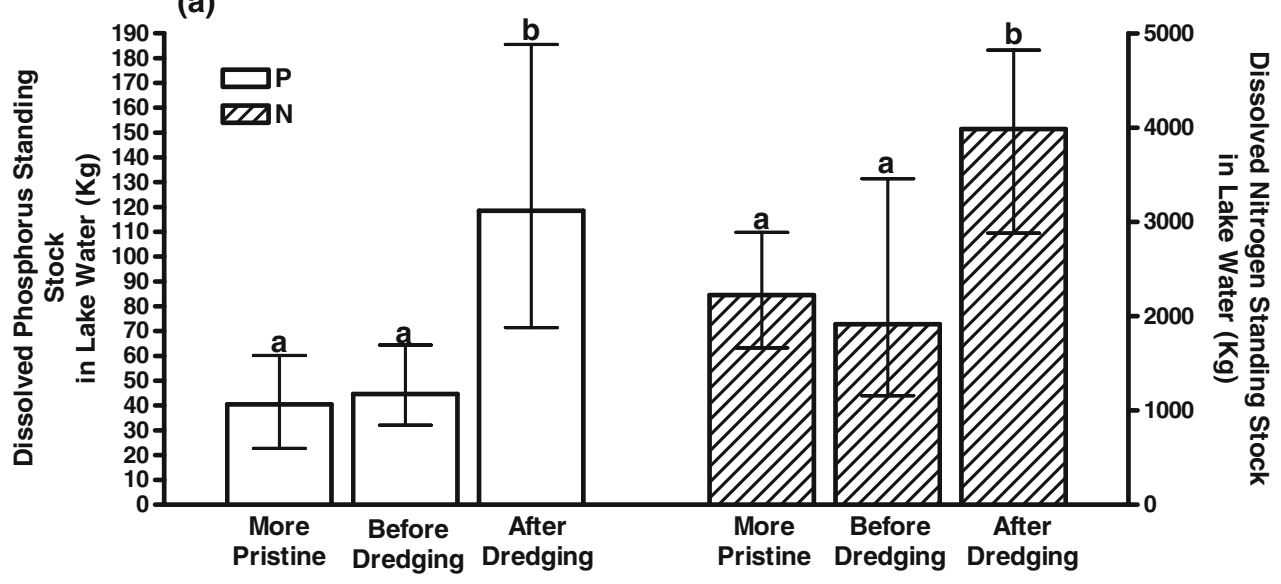

(b)

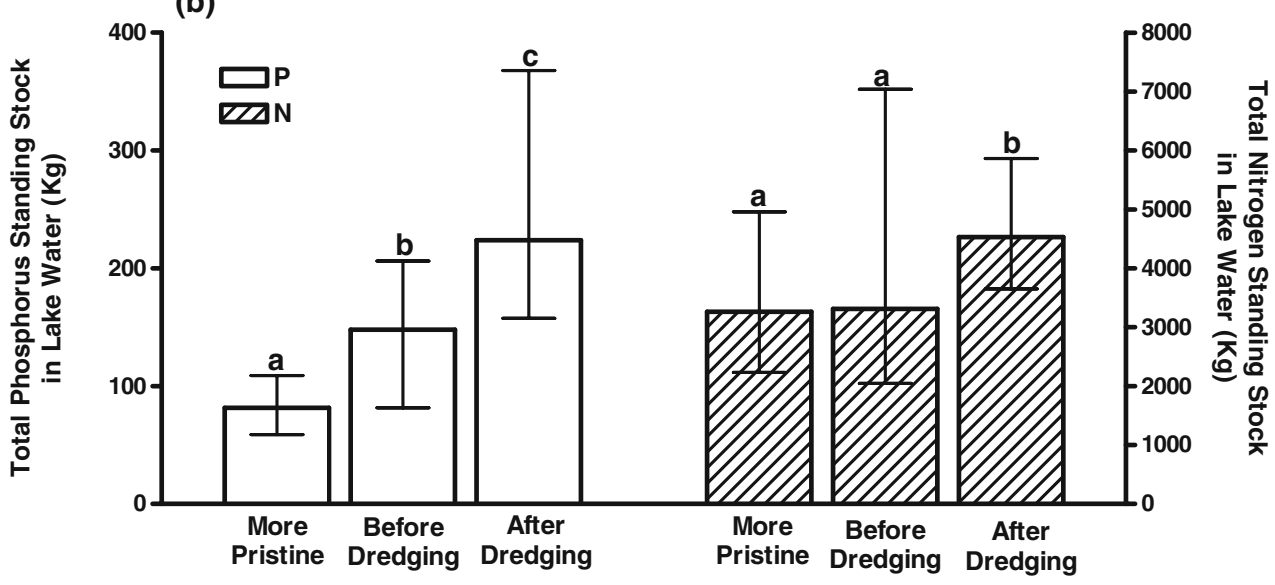


Table 1 Dredging effects on standing stock of total nitrogen $(\mathrm{N})$ and phosphorus $(\mathrm{P})$ in the waters of Imboassica Lake

\begin{tabular}{lllll}
\hline $\begin{array}{l}\text { Standing stock } \\
\text { of total nutrients }\end{array}$ & Time intervals & Absolute increase $(\mathrm{kg})$ & Increase rate $\left(\mathrm{kg} \mathrm{year}^{-1}\right)$ & Dredging effects in water $\left(\mathrm{kg}\right.$ year $\left.{ }^{-1}\right)$ \\
\hline Nitrogen & Between BD and PRIST & $\mathrm{ns}^{\mathrm{a}}$ & $\mathrm{ns}$ & 1,222 \\
& Between AD and BD & 1,222 & 1,222 & 63 \\
Phosphorus & Between BD and PRIST & 66 & 13 & 76 \\
& Between AD and BD & 76 & & \\
\hline
\end{tabular}

${ }^{\text {a }}$ No significant increase

and Kalff 2001) from aquatic ecosystems. In our study, the removal of aquatic macrophytes with decreases in water residence time by dredging was related to a strong increase in $\mathrm{N}$ and $\mathrm{P}$ standing stocks in Imboassica Lake.

Retention of $\mathrm{N}$ and $\mathrm{P}$ per area in this tropical wetland, which is densely colonized by aquatic macrophytes, was estimated as about two orders of magnitude lower than often described for N (Arheimer and Wittgren 2002; Jiang et al. 2007; Blankenberg et al. 2008) and P (Uusi-Kamppa et al. 2000; Jiang et al. 2007) in highly nutrient-enriched constructed wetlands (effluent treatment systems). However, nutrient retention in the Imboassica river-lake system before dredging was comparable or higher than one currently described in natural or more oligotrophic constructed wetlands for N (Jansson et al. 1998; Fisher and Acreman 2004; Silvan et al. 2004) and P (Mitsch and Reeder 1991; Fisher and Acreman 2004; Silvan et al. 2004). Therefore, our results confirm the potential role of aquatic macrophytes in retaining excess nutrients (Hutchinson 1970; Demars and Harper 1998), and in reducing nutrient pollution of eutrophic lakes (Steinmann et al. 2003).

The removal of internal nutrient loading in the watersediment interface by dredging with increases in the water flow can contribute to the restoration of aquatic ecosystems (Lohrer and Wetz 2003; Jiang and Shen 2006), but this intervention was related positively to nutrient enrichment in the studied lake. Many studies have independently assessed the role of dredging (Sagehashi et al. 2001) and aquatic vegetation (Steinmann et al. 2003) on the mitigation of aquatic eutrophication. On the other hand, the effects of drastic removal of large stands of aquatic macrophytes by dredging are still not well known. Our results suggest that eutrophication in a shallow tropical lake was significantly enhanced after dredging, confirming the proposed hypothesis. In conclusion, dredging may be considered an effective engineering technology for restoration of lakes (Jiang and Shen 2006), but might intensify rather than mitigate eutrophication when the removal of aquatic macrophytes is coupled with continued anthropogenic nutrient input. Dredging needs integrated planning related to decreases in nutrient inputs from the watershed, especially in tropical shallow lakes where aquatic macrophytes may be important players in nutrient cycling.

Acknowledgments The authors would like to acknowledge PETROBRAS for financial support of the ECOLagoas Project and logistic support in NUPEM/UFRJ. We wish to thank Dr. David Bastviken for useful advice, and the two anonymous reviewers for valuable comments on an earlier draft of this manuscript. We are also grateful to the Brazilian funding agencies FAPERJ, CAPES and $\mathrm{CNPq}$ for scholarships and financial support.

\section{References}

Arbuckle, K.E., and J.A. Downing. 2001. The influence of watershed land use on lake $\mathrm{N}: \mathrm{P}$ in a predominantly agricultural landscape. Limnology and Oceanography 46:970-975.

Arheimer, B., and H.B. Wittgren. 2002. Modelling nitrogen removal in potential wetlands at the catchment scale. Ecological Engineering 19:63-80.

Benjamini, Y., and Y. Hochberg. 1995. Controlling the false discovery rate - a practical and powerful approach to multiple testing. Journal of the Royal Statistical Society Series B-Methodological 57:289-300.

Blankenberg, A.-G.B., K. Haarstad, and A.-K. Søvik. 2008. Nitrogen retention in constructed wetland filters treating diffuse agriculture pollution. Desalination 226:114-120.

Brevik, E.C., and J.A. Homburg. 2004. A 5000 year record of carbon sequestration from a coastal lagoon and wetland complex, Southern California, USA. Catena 57:221-232.

Costa-Pierce, B.A. 1998. Preliminary investigation of an integrated aquaculture-wetland ecosystem using tertiary-treated municipal wastewater in Los Angeles County, California. Ecological Engineering 10:341-354.

Demars, B.O.L., and D.M. Harper. 1998. The aquatic macrophytes of an English lowland river system: assessing response to nutrient enrichment. Hydrobiologia 384:75-88.

Downing, J.A., Y.T. Prairie, J.J. Cole, C.M. Duarte, L.J. Tranvik, R.G. Striegl, W.H. McDowell, P. Kortelainen, N.F. Caraco, J.M. Melack, and J.J. Middelburg. 2006. The global abundance and size distribution of lakes, ponds, and impoundments. Limnology and Oceanography 51:2388-2397.

Fisher, J., and M.C. Acreman. 2004. Wetland nutrient removal: a review of the evidence. Hydrology and Earth System Sciences 8:673-685.

Fleischer, S., L. Stibe, and L. Leonardson. 1991. Restoration of wetlands as a means of reducing nitrogen transport to coastal waters. Ambio 20:271-272. 
Garcia, L.V. 2004. Escaping the Bonferroni iron claw in ecological studies. Oikos 105:657-663.

Golterman, H.L., R.S. Clymo, and M.A.M. Ohnstad. 1978. Methods for physical and chemical analysis of fresh water. Oxford: Blackwell Scientific.

Gophen, M. 2000. Nutrient and plant dynamics in Lake Agmon Wetlands (Hula Valley, Israel): a review with emphasis on Typha domingensis (1994-1999). Hydrobiologia 441:25-36.

Hutchinson, G. 1970. Chemical ecology of 3 species of myriophyllum (Angiospermae, Haloragaceae). Limnology and Oceanography $15: 1-15$.

Jansson, A., C. Folke, and S. Langaas. 1998. Quantifying the nitrogen retention capacity of natural wetlands in the large-scale drainage basin of the Baltic Sea. Landscape Ecology 13:249-262.

Jiang, J.G., and Y.F. Shen. 2006. Estimation of the natural purification rate of a eutrophic lake after pollutant removal. Ecological Engineering 28:166-173.

Jiang, C.L., X.Q. Fan, G.B. Cui, and Y.B. Zhang. 2007. Removal of agricultural non-point source pollutants by ditch wetlands: implications for lake eutrophication control. Hydrobiologia 581:319-327.

Kadlec, R.H. 1997. An autobiotic wetland phosphorus model. Ecological Engineering 8:145-172.

Kadlec, R.H., and R.L. Knight. 1996. Treatment wetlands. New York: Lewis.

Lennon, J.T. 2004. Experimental evidence that terrestrial carbon subsidies increase $\mathrm{CO}_{2}$ flux from lake ecosystems. Oecologia 138:584-591.

Lohrer, A.M., and J.J. Wetz. 2003. Dredging-induced nutrient release from sediments to the water column in a southeastern saltmarsh tidal creek. Marine Pollution Bulletin 46:1156-1163.

Lopes-Ferreira, C. 1998. Reduction of nitrogen and phosphorus concentrations from sewage inputs by an aquatic macrophytes stand in Imboassica Lagoon (in portuguese). In: Ecology of Coastal Lagoons (in portuguese), ed. Esteves F. A., 375-390. Macaé: NUPEM/UFRJ.

Mackereth, F.J.H., J. Heron, and J.F. Talling. 1978. Water Analysis: some revised methods for limnologists. Freshwater Biological Association Scientific Publication n. 36. Windermere: Cumbria and Dorser.

Mitsch, W.J., and B.C. Reeder. 1991. Modeling nutrient retention of a fresh-water coastal wetland - estimating the roles of primary productivity, sedimentation, resuspension and hydrology. Ecological Modelling 54:151-187.

Neue, H.U., J.L. Gaunt, Z.P. Wang, P. BeckerHeidmann, and C. Quijano. 1997. Carbon in tropical wetlands. Geoderma 79:163-185.

Palma-Silva, C. 1998. Growth and production of Typha domingensis Pers in Imboassica lagoon (in portuguese). In Ecology of coastal lagoons (in portuguese), ed. F. A. Esteves, 205-220. Rio de Janeiro: NUPEM/UFRJ.

Rooney, N., J. Kalff, and C. Habel. 2003. The role of submerged macrophyte beds in phosphorus and sediment accumulation in Lake Memphremagog, Quebec, Canada. Limnology and Oceanography 48:1927-1937.

Ruley, J.E., and K.A. Rusch. 2002. An assessment of long-term post-restoration water quality trends in a shallow, subtropical, urban hypereutrophic lake. Ecological Engineering 19:265280.

Sagehashi, M., A. Sakoda, and M. Suzuki. 2001. A mathematical model of a shallow and eutrophic lake (the Keszthely Basin, Lake Balaton) and simulation of restorative manipulations. Water Research 35:1675-1686.

Saunders, D.L., and J. Kalff. 2001. Nitrogen retention in wetlands, lakes and rivers. Hydrobiologia 443:205-212.

Schindler, D.W. 2006. Recent advances in the understanding and management of eutrophication. Limnology and Oceanography 51:356-363.

Silva, E. 2006. Levels of total and thermotolerant coliforms in Imboassica lagoon: a thirteen years analysis (in portuguese). Bachelor's Thesis. Rio de Janeiro: Federal University of Rio de Janeiro.

Silvan, N., H. Vasander, and J. Laine. 2004. Vegetation is the main factor in nutrient retention in a constructed wetland buffer. Plant and Soil 258:179-187.

Sobek, S., L.J. Tranvik, and J.J. Cole. 2005. Temperature independence of carbon dioxide supersaturation in global lakes. Global Biogeochemical Cycles 19:1-10.

Steinmann, C.R., S. Weinhart, and A. Melzer. 2003. A combined system of lagoon and constructed wetland for an effective wastewater treatment. Water Research 37:2035-2042.

Uusi-Kamppa, J., B. Braskerud, H. Jansson, N. Syversen, and R. Uusitalo. 2000. Buffer zones and constructed wetlands as filters for agricultural phosphorus. Journal of Environmental Quality 29:151-158.

Verhoeven, J.T.A., and A.F.M. Meuleman. 1999. Wetlands for wastewater treatment: Opportunities and limitations. Ecological Engineering 12:5-12.

Wentz, W.A. 1987. Ecological /Environmental perspectives on the use of wetlands in water treatment. In Aquatic Plants for Water Treatment and Resource Recovery, ed. Reddy K. R. and Smith W. H., 17-25. Orlando: Magnolia.

Wetzel, R.G. 1990. Land-water interfaces: Metabolic and limnological regulators. Vereinigung für Theoretische und Angewandte Limnologie 24:6-24.

Zar, J.H. 1996. Biostatistical analysis. New Jersey: Prentice Hall. 